\title{
Critically appraised topic on adverse food reactions of companion animals (2): common food allergen sources in dogs and cats
}

Ralf S. Mueller ${ }^{1}$, Thierry Olivry ${ }^{2^{*}}$ and Pascal Prélaud ${ }^{3}$

\begin{abstract}
Background: To diagnose cutaneous adverse food reactions (CAFRs) in dogs and cats, dietary restriction-provocation trials are performed. Knowing the most common offending food allergens for these species would help determining the order of food challenges to optimize the time to diagnosis.

Results: The search for, and review and analysis of the best evidence available as of January 16, 2015 suggests that the most likely food allergens contributing to canine CAFRs are beef, dairy products, chicken, and wheat. The most common food allergens in cats are beef, fish and chicken.

Conclusions: In dogs and cats, after a period of dietary restriction leading to the complete remission of clinical signs, food challenges to diagnose CAFR should begin with beef and dairy products, the most commonly recognized food allergens in these two species.
\end{abstract}

Keywords: Allergen, Allergy, Atopic dermatitis, Canine, Cat, Dietary, Dog, Feline, Food allergy

\section{Background}

The diagnosis of cutaneous adverse food reactions (CAFRs) in dogs and cats relies on the performance of dietary restriction-provocation trials. Knowing the most common offending allergens in these species would help determine which food challenges should be performed first to faster confirm the diagnosis of CAFR.

\section{Clinical scenarios}

You have two patients: The first is a 1-year-old male Labrador retriever with a 3-month history of pruritus and recurrent mucous diarrhea. This dog has been eating a commercial diet for the last 6 months. On physical examination, you do not detect anomalies besides soft stools on rectal palpation. Your second patient is a 2-year-old female spayed Persian cat that has been scratching her face for the last year. This self-trauma

\footnotetext{
*Correspondence: tolivry@ncsu.edu

2Department of Clinical Sciences, College of Veterinary Medicine, North Carolina State University, Raleigh, NC, USA

Full list of author information is available at the end of the article
}

only responds partially to high dose of prednisolone. Physical examination reveals the cat to be thinner than expected and to have excoriations on the head and neck. You suspect that both patients could be reactive to their commercial diets, but you wonder which one of the ingredients listed on the labels would be the most likely sources of allergens.

\section{Structured question}

In dogs and cats suspected of CAFR, which food sources are most often reported to induce clinical signs after challenge?

\section{Search strategy}

The CAB Abstracts and Web of Science (Science Citation Index Expanded) databases were searched on January 16, 2015, using the following string: ((dog or dogs or canine) or (cat or cats or feline)) and (food or diet*) and (allerg* or atop* or hypersens* or intolerance). The search was limited to the period 1985 to 2015. Bibliographies of 
identified articles were then further searched for additional relevant reports.

\section{Identified evidence}

Our literature search identified 140 and 1534 citations in CAB Abstracts and Web of Science, of which three [1-3] and 15 [1, 3-17] respectively contained relevant information. Citations that were not selected were those of articles not specifically identifying offending allergens in dogs and cats exhibiting clinical signs of CAFR. Six more relevant citations were identified in the bibliography of articles found with the electronic search [18-22], and three sources were abstracts of recent conference proceedings [23-25]. Offending allergens were reported in case reports $[12,14,18,22,26]$ or case series of dogs and cats with clinical evidence of adverse food reaction $[1-5,7,10,13$, $16,19,25,27]$, in studies evaluating diagnostic techniques for adverse food reactions [5, 8, 9, 11, 17, 23, 24] or (rarely) in studies evaluating reaction patterns such as vasculitis or symmetrical lupoid onychitis with multiple

Table 1 Details of studies about allergens suspected of causing CAFRs in cats

\begin{tabular}{|c|c|c|c|c|}
\hline Reference & $\begin{array}{l}\text { Number } \\
\text { of dogs }\end{array}$ & $\begin{array}{l}\text { Number of individual } \\
\text { rechallenges per dog }\end{array}$ & Details of rechallenges & Offending allergens and comments \\
\hline Walton [2] & 82 & unclear & unclear & $\begin{array}{l}\text { cow's milk (22), tinned food (16), beef } \\
(13), \text { wheat (11), mutton (6), egg, pork } \\
\text { ( } 3 \text { each), herring ( } 2) \text {, cod, maize, rabbit, } \\
\text { dog biscuits, kidney bean ( } 1 \text { each) }\end{array}$ \\
\hline Chesney [4] & 19 & $\begin{array}{l}\text { unclear, but only } 9 \text { owners } \\
\text { rechallenged their dogs }\end{array}$ & unclear & $\begin{array}{l}\text { beef (4), milk (3), chicken, dog biscuit } \\
\text { ( } 2 \text { each), cheese, turkey, pork ( } 1 \text { each) }\end{array}$ \\
\hline Guilford et al. [5] & 8 & 3 to 6 & $\begin{array}{l}\text { rechallenge with corn, soy, cow's milk } \\
\text { ( } 8 / 8 \text { each), wheat }(2 / 8) \text {, lamb }(7 / 8) \text {, } \\
\text { beef }(3 / 8)(14-16 \mathrm{~g} \text { of each, once daily } \\
\text { for } 14 \text { days) }\end{array}$ & corn (2), wheat, milk (1 each) \\
\hline Harvey [7] & 25 & at least 6 & $\begin{array}{l}1 \text { week of beef, milk, cheese, egg, mixer } \\
\text { biscuit, bread in all dogs, additionally } \\
\text { chicken, lamb and chocolate one each } \\
\text { in } 3 \text { of the dogs }\end{array}$ & $\begin{array}{l}\text { bread and mixer biscuit (same } 7 \text { dogs), } \\
\text { cheese and milk (same } 7 \text { dogs), beef ( } 2 \text { ), } \\
\text { egg, lamb, chocolate ( } 1 \text { each) }\end{array}$ \\
\hline Ishida et al. [8] & 8 & 9 & $\begin{array}{l}\text { beef, chicken, chicken egg, wheat, corn, } \\
\text { rice, tuna, cod, milk (increasing to } 120 \mathrm{~g} \\
\text { daily for } 7 \text { days) }\end{array}$ & $\begin{array}{l}\text { beef (5), rice ( } 3) \text {, egg, wheat, cod ( } 1 \\
\text { each) }\end{array}$ \\
\hline Jeffers et al. [9] & 13 & 6 & $\begin{array}{l}\text { beef, cow's milk, chicken, chicken egg, } \\
\text { soybean, wheat for } 1 \text { week each }\end{array}$ & $\begin{array}{l}\text { beef (12), milk (5), wheat (4), chicken, } \\
\text { soybean ( } 3 \text { each), egg ( } 2 \text { ) }\end{array}$ \\
\hline Jeffers et al. [10] & 25 & 5 & $\begin{array}{l}\text { beef, chicken, chicken eggs, cow's milk, } \\
\text { soy for } 1 \text { week each }\end{array}$ & $\begin{array}{l}\text { beef (15), soy (8), chicken, milk (7 each), } \\
\text { wheat (6), } 5 \text { (egg) }\end{array}$ \\
\hline Mueller and Tsohalis [11] & 8 & unclear & unclear & beef (7), dairy (1), chicken (1) \\
\hline Ohmori et al. [12] & 1 & unclear & unclear & beef \\
\hline Paterson [13] & 20 & at least 5 & $\begin{array}{l}\text { Beef, dairy products, wheat, lamb and } \\
\text { chicken for one week each as one } \\
\text { additional test meal while on elimination } \\
\text { diet followed by other allergens based } \\
\text { on diet history }\end{array}$ & $\begin{array}{l}\text { beef (13), lamb (5), gluten, egg ( } 4 \text { each), } \\
\text { chicken, milk, pork ( } 2 \text { each), soy, corn } \\
\text { (1 each) }\end{array}$ \\
\hline Salzo [16] & 20 & unclear & 7 days of rechallenge & $\begin{array}{l}\text { beef }(11) \text {, chicken }(7) \text {, rice }(5) \text {, milk, wheat } \\
\text { (1 each) }\end{array}$ \\
\hline Vaden et al. [17] & 6 & 7 & $\begin{array}{l}1 \text { meal containing a different allergen } \\
\text { every other day }\end{array}$ & $\begin{array}{l}\text { chicken, corn ( } 5 \text { each), tofu (3), cottage } \\
\text { cheese, wheat, lamb (2) }\end{array}$ \\
\hline Coyner [18] & 1 & 1 & unclear & beef \\
\hline Mueller et al. [20] & 1 & 5 & $\begin{array}{l}\text { rechallenge with beef, cow's milk, } \\
\text { chicken, mutton, wheat, details unclear }\end{array}$ & beef \\
\hline Nicholls et al. [21] & 2 & unclear & unclear & beef (2) \\
\hline Johansen et al. [23] & 4 & unclear & unclear & beef (2), pork, salmon (1 each) \\
\hline Johansen et al. [24] & 5 & unclear & unclear & $\begin{array}{l}\text { chicken (5), corn (3), but preselected out } \\
\text { of a population with such allergies }\end{array}$ \\
\hline Tarpataki and Nagy [25] & 39 & unclear & unclear & chicken (16), beef (12) \\
\hline Fujimura et al. [26] & 1 & 1 & $\begin{array}{l}10 \mathrm{~g} \text { of fresh tomato led to } \\
\text { clinical signs within } 30 \text { minutes }\end{array}$ & tomato \\
\hline
\end{tabular}


causes [20,21]. A positive rechallenge was considered the only solid evidence for identifying an offending allergen. From these selected publications, we added the number of cases in which positive challenges had occurred with the various food items, and the frequency of reaction among total number of dogs was calculated.

\section{Evaluation of evidence}

Altogether, at least one offending food allergen source was reported in each of the 297 dogs included in the selected studies $[2,4,5,7-13,16-18,20,21,23-26]$ (Table 1). The most frequently reported food allergens involved in CAFRs in dogs were beef (102 dogs, $34 \%$ ), dairy products (51 dogs, $17 \%$ ), chicken (45 dogs, $15 \%$ ), wheat (38 dogs, $13 \%)$ and lamb (14, $5 \%)$. Other less commonly reported offending food sources were soy (18 dogs, $6 \%$ ), corn (13 dogs, $4 \%$ ), egg (11 dogs, $4 \%$ ), pork (7 dogs, $2 \%$ ), fish and rice ( 5 dogs each, $2 \%$ ). Barley, rabbit, chocolate, kidney bean and tomato were also reported as food allergens for single dogs.

At least one food allergen was identified in each one of the 78 cats reported in selected articles $[1-3,6,14$, 19, 22, 27] (Table 2) . The food sources most frequently causing CAFR in cats were beef (14 cats, $18 \%$ ), fish (13 cats, $17 \%$ ), chicken (4 cats, $5 \%$ ), wheat, corn and dairy products (3 cats each, $4 \%$ ) and lamb (2 cats, $3 \%$ ). Egg, barley and rabbit were also reported as offending allergens in individual cats.

There were several limitations in interpreting the data presented. In most studies details of the provocation with individual allergens were not provided. Furthermore, most reports only listed allergens associated with a deterioration of signs upon rechallenge, but not those associated with negative provocations; this could possibly bias the estimation of the prevalence of offending allergens. Only five studies had used a standardized rechallenge sequence in dogs $[7-10,13]$. In these studies, beef, chicken, wheat, soy and dairy products were the most common involved allergens, reflecting the data gathered from the literature. In cats, only one study attempted those uniform provocations [27], and beef, fish and chicken were the allergens most commonly involved in that study. In addition the previous diet history was generally not provided, thereby preventing a clinically relevant interpretation of the data. Thus, the information gathered herein does not allow a true estimate of the prevalence of offending allergens nor any statement about the likelihood of positive provocations in relation to previously fed foods. Finally, the offending allergens found herein could merely reflect pet feeding habits in the preceding decades, and these allergens could change once new pet foods become fashionable and used more frequently.

\section{Conclusion and implication for practitioners}

In a dog living in Australia, Europe or North America, the allergens most likely contributing to CAFRs are beef, dairy products, chicken, wheat and lamb. As a result, these foods should be the first used for allergen provocation for CAFR diagnosis. In cats, the most common allergens causing CAFRs are beef, fish and chicken.

Importantly, the identified evidence does not allow an estimation of the real prevalence of offending allergens in the population of dogs and cats with CAFR, as animals were usually only challenged with a small number of-but not all- allergens. As a result, the true

Table 2 Details of studies about allergens suspected of causing CAFRs in cats

\begin{tabular}{|c|c|c|c|c|}
\hline Reference & $\begin{array}{l}\text { Number } \\
\text { of cats }\end{array}$ & $\begin{array}{l}\text { Number of individual } \\
\text { rechallenges per cat }\end{array}$ & Details of rechallenges & Offending allergens and comments \\
\hline Stogdale [1] & 2 & $\begin{array}{l}6 \text { in } 1 \text { cat, unclear in } \\
\text { the other }\end{array}$ & $\begin{array}{l}\text { Chicken, fish, beef, horse, mutton, milk in } \\
\text { one cat, various fresh meats and commercial } \\
\text { foods in the other cat, details unclear }\end{array}$ & $\begin{array}{l}\text { chicken, fish, beef in the first cat,and not } \\
\text { chicken and fish in the other cat } \\
\text { (all other meats led to deterioration) }\end{array}$ \\
\hline Walton [2] & 18 & unclear & unclear & $\begin{array}{l}\text { cow's milk ( } 7) \text {, beef (5), rabbit, chicken, } \\
\text { whale meat ( } 1 \text { each) }\end{array}$ \\
\hline White and Sequoia [3] & 14 & unclear & $\begin{array}{l}\text { various commercial diets, dairy products, } \\
\text { fish were administered to } 11 \text { of } 14 \text { cats } \\
\text { further details were not provided }\end{array}$ & fish (6), dairy products (2) \\
\hline Guilford et al. [6] & 16 & $\begin{array}{l}\text { unclear, depending } \\
\text { on the diet history }\end{array}$ & $15-50 \mathrm{~g}$ of allergen daily for 7 days & $\begin{array}{l}\text { beef, corn, wheat ( } 3 \text { each), gluten, barley, } \\
\text { chicken, lamb, sardines, lactose, viscera, } \\
\text { food additives (1 each) }\end{array}$ \\
\hline Reedy [14] & 1 & 2 & 3 days of tuna and lamb & tuna, lamb (1) \\
\hline Guaguère [19] & 10 & unclear & 2 weeks with each allergen & beef (4), milk (3), fish (2), egg (1) \\
\hline Walton et al. [22] & 1 & unclear & 7 days with each allergen & milk \\
\hline Vogelnest and Cheng [27] & 17 & & $\begin{array}{l}\text { beef, chicken, lamb, fish, diary, wheat for } \\
7 \text { days each (attempted only in } 8 \text { cats and } \\
\text { completed in } 6 \text { of them) }\end{array}$ & fish (2), chicken (1), beef (1) \\
\hline
\end{tabular}


prevalence of each offending allergens in dogs and cats is likely to be higher than that reported above.

Importantly, all these estimates of prevalence will need to be reevaluated with prospective studies performing controlled rechallenges in a larger number of animals with a detailed history of their previous dietary exposure.

\section{Abbreviations}

CAFR: cutaneous adverse food reaction; CAT: critically-appraised topic

\section{Competing interests}

In the past three years, the three authors have lectured for, and received research funding and/or consulting honoraria from Royal Canin (Aimargues, France), which paid publication charges for this article.

\section{Authors' contributions}

The three authors selected the topic of this CAT. RSM performed the literature search, extracted and summarized the evidence. TO and PP verified the evidence and TO wrote the first draft of the article. The three authors edited and then approved the final manuscript.

\section{Acknowledgements}

The authors thank Drs. Philippe Marniquet, Isabelle Mougeot and Sara Soler from Royal Canin for the initiation and support of this series of critically appraised topics on adverse food reactions and for paying publication charges for this article.

\section{Author details}

${ }^{1}$ Medizinische Kleintierklinik, Centre for Clinical Veterinary Medicine, Ludwig Maximilian University, Munich, Germany. ${ }^{2}$ Department of Clinical Sciences, College of Veterinary Medicine, North Carolina State University, Raleigh, NC, USA. ${ }^{3}$ Clinique Advetia, Paris, France.

Received: 10 July 2015 Accepted: 3 November 2015

Published online: 12 January 2016

\section{References}

1. Stogdale L, Bomzon L, Bland van den Berg P. Food allergy in cats. J Am Anim Hosp Assoc. 1982;18:188-94.

2. Walton GS. Skin responses in the dog and cat to ingested allergens. Vet Rec. 1967:81:709-13.

3. White SD, Sequoia D. Food hypersensitivity in cats: 14 cases (1982-1987) J Am Vet Med Assoc. 1989:194:692-5.

4. Chesney CJ. Food sensitivity in the dog: a quantitative study. J Small Anim Pract. 2002:43:203-7.

5. Guilford WG, Strombeck DR, Rogers Q, et al. Development of gastroscopic food sensitivity testing in dogs. J Vet Intern Med. 1994:8:414-22.

6. Guilford WG, Jones BR, Markwell PJ, et al. Food sensitivity in cats with chronic idiopathic gastrointestinal problems. J Vet Intern Med. 2001:15:7-13.

7. Harvey RG. Food allergy and dietary intolerance in dogs - a report of 25 cases. J of Small Animal Pract. 1993;34:175-9.

8. Ishida R, Masuda K, Sakaguchi M, et al. Antigen-specific histamine release in dogs with food hypersensitivity. J Vet Med Sci. 2003;65:435-8.

9. Jeffers JG, Shanley KJ, Meyer EK. Diagnostic testing of dogs for food hypersensitivity. J Am Vet Med Assoc. 1991;198:245-50.

10. Jeffers JG, Meyer EK, Sosis EJ. Responses of dogs with food allergies to single-ingredient dietary provocation. J Am Vet Med Assoc. 1996;209:608-11.

11. Mueller RS, Tsohalis J. Evaluation of serum allergen-specific lgE for the diagnosis of food adverse reactions in the dog. Vet Dermatol. 1998;9:167-71.

12. Ohmori K, Masuda K, Kawarai S, et al. Identification of bovine serum albumin as an IgE-reactive beef component in a dog with food hypersensitivity against beef. J Vet Med Sci. 2007:69:865-7.

13. Paterson S. Food hypersensitivity in 20 dogs with skin and gastrointestinal signs. J Small Anim Pract. 1995;36:529-34.

14. Reedy LM. Food hypersensitivity to lamb in a cat. J Am Vet Med Assoc. 1994;204:1039-40

15. Roudebush P. Ingredients and foods associated with adverse reactions in dogs and cats. Vet Dermatol. 2013;24:293-4.

16. Salzo PS, Larsson CE. Hipersensibilidade alimentar em caes. Arq Bras Med Vet Zootec. 2009;61:598-605.
17. Vaden SL, Hammerberg B, Davenport DJ, et al. Food hypersensitivity reactions in Soft Coated Wheaten Terriers with protein-losing enteropathy or protein-losing nephropathy or both: gastroscopic food sensitivity testing, dietary provocation, and fecal immunoglobulin E. J Vet Intern Med. 2000;14:60-7.

18. Coyner K. Otomycosis due to Aspergillus spp. in a dog: case report and literature review. Vet Dermatol. 2010;21:613-8.

19. Guaguère E. Intolérance alimentaire à manifestations cutanées: à propos de 17 cas chez le chat. Prat Med Chir Anim Comp. 1993:28:451-60.

20. Mueller RS, Friend S, Shipstone MA, et al. Diagnosis of claw disease - a prospective study of 24 dogs. Vet Dermatol. 2000;11:133-41.

21. Nichols PR, Morris DO, Beale KM. A retrospective study of canine and feline cutaneous vasculitis. Vet Dermatol. 2001:12:255-64.

22. Walton GS, Parish WE, Coombs RRA. Spontaneous allergic dermatitis and enteritis in a cat. Vet Rec. 1968:83:35-41.

23. Johansen C, Mariani C, Mueller RS. Patch testing with predigested proteins in sensitized dogs. Vet Dermatol. 2012;23:61. abstract.

24. Johansen C, Mariani C, Mueller RS. Patch testing with feather hydrolysate, corn starch and a commercial diet containing corn starch and feather hydrolysate in chicken- and corn-allergic dogs. Vet Dermatol. 2012;23:62. abstract.

25. Tarpataki N, Nagy T. The occurence and the features of food allergy in Hungarian dogs. Vet Dermatol. 2012;23:55. abstract.

26. Fujimura M, Ohmori K, Masuda K, et al. Oral allergy syndrome induced by tomato in a dog with Japanese cedar (Cryptomeria japonica) pollinosis. J Vet Med Sci. 2002;64:1069-70.

27. Vogelnest $\sqcup$, Cheng KY. Cutaneous adverse food reactions in cats: retrospective evaluation of 17 cases in a dermatology referral population (2001-2011). Aust Vet J. 2013:91:443-51.

\section{Submit your next manuscript to BioMed Central and take full advantage of:}

- Convenient online submission

- Thorough peer review

- No space constraints or color figure charges

- Immediate publication on acceptance

- Inclusion in PubMed, CAS, Scopus and Google Scholar

- Research which is freely available for redistribution

Submit your manuscript at www.biomedcentral.com/submit
C BioMed Central 